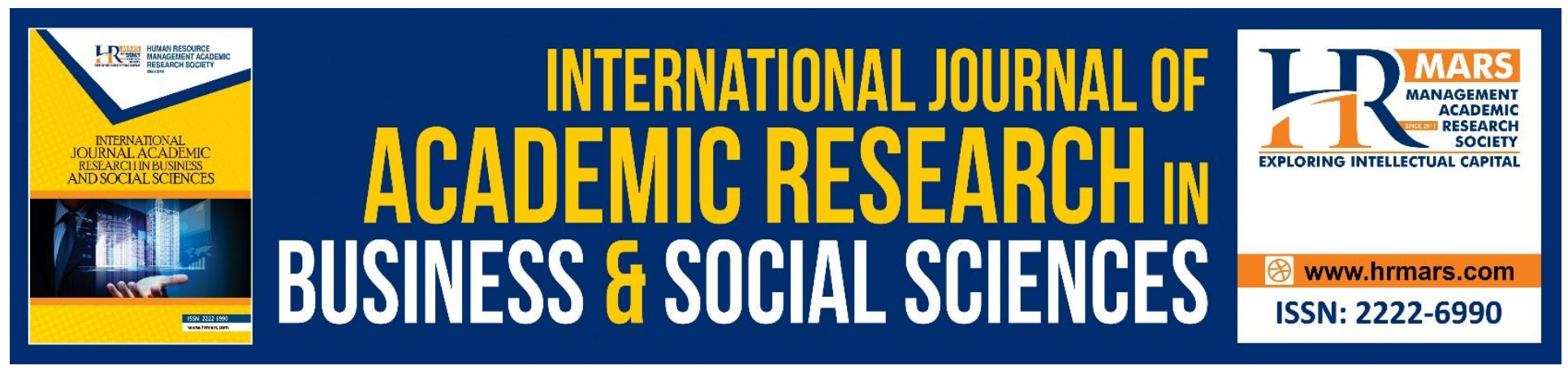

\title{
Waqf and Provision of Social Services in Kaduna State: Contributions and Challenges
}

\author{
Gidado, Abdu Dauda and Abubakar Muhammad Sani
}

To Link this Article: http://dx.doi.org/10.6007/IJARBSS/v8-i6/4314

DOI: $\quad 10.6007 /$ IJARBSS/v8-i6/4314

Received: 28 May 2018, Revised: 26 June 2018, Accepted: 29 June 2018

Published Online: 08 July 2018

In-Text Citation: (Gidado \& Sani, 2018)

To Cite this Article: Gidado, A. D., \& Sani, A. M. (2018). Waqf and Provision of Social Services in Kaduna State: Contributions and Challenges. International Journal of Academic Research in Business and Social Sciences, 8(6), 1207-1215.

Copyright: (C) 2018 The Author(s)

Published by Human Resource Management Academic Research Society (www.hrmars.com)

This article is published under the Creative Commons Attribution (CC BY 4.0) license. Anyone may reproduce, distribute, translate and create derivative works of this article (for both commercial and non-commercial purposes), subject to full attribution to the original publication and authors. The full terms of this license may be seen at: http://creativecommons.org/licences/by/4.0/legalcode

Vol. 8, No. 6, June 2018, Pg. 1207 - 1215

Full Terms \& Conditions of access and use can be found at http://hrmars.com/index.php/pages/detail/publication-ethics 


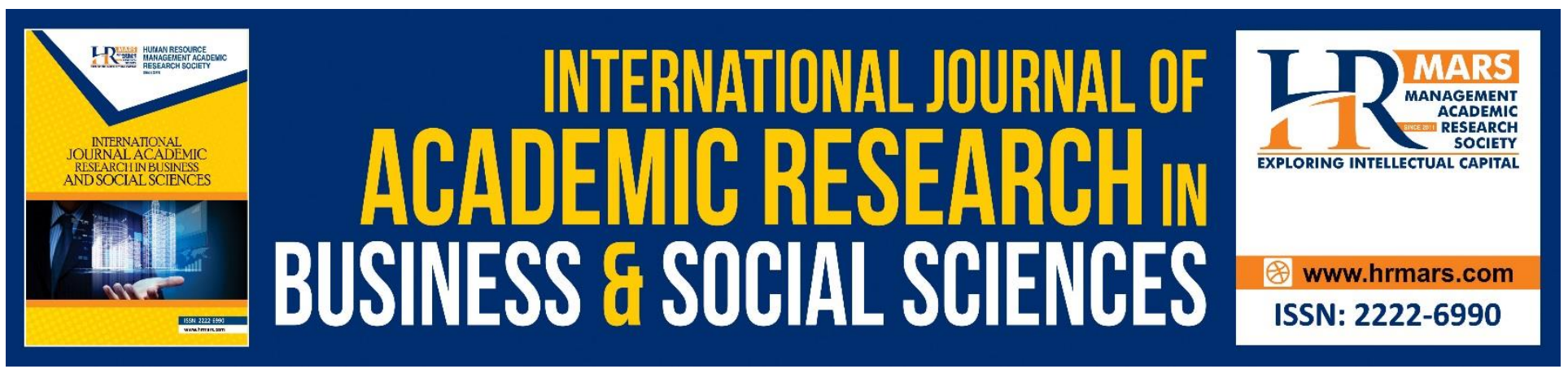

\title{
Waqf and Provision of Social Services in Kaduna State: Contributions and Challenges
}

\author{
Gidado, Abdu Dauda \\ School of Preliminary and Remedial Studies, Kaduna Polytechnic, Kaduna-Nigeria \\ Email: Agdgidado2@yahoo.com
}

\begin{abstract}
Abubakar Muhammad Sani, PhD
Islamic Studies Section, Department Arts and Social Sciences Education, Ahmadu Bello University, Zaria-Nigeria
\end{abstract}

\begin{abstract}
This study was conducted in order to determine the contributions of Awqaf to the provision of social services in Kaduna State as well as the challenges confronting the institution in the State. The study had two research objectives and two research questions. The study adopted the survey research design and the population of the study was made up of all the donors, administrators and beneficiaries of Awqaf in Kaduna State. The data were collected through a structured interview. The findings of the study revealed that the institution of Awqaf contributes to provision of social services such as schools, skills acquisition centres, medical centres, orphanage homes, libraries and cemeteries in Kaduna State. The study also revealed that the greatest challenges to Awqaf in Kaduna State are low participation and the dissolution of the Kaduna State Standing Committee on Zakat and Waqf. The study concluded that waqf is a social insurance scheme which contributes towards the provision of social services to which all well-to-do Muslims in the society are expected to contribute, in order to cater for the needy, underprivileged ones and the society at large. As a way forward, the study among others recommends that there should be increase in volume of skills acquisition centres, medical centres and libraries provided through the institution of Awqaf and the Kaduna State Government should reintroduce the Zakat and Waqf Board.
\end{abstract}

Keywords: Waqf, Provision, Social Services, Contributions, Challenges

\section{Introduction}

The Islamic religion gives recognition to charity which shows that it cares for people with low social status and the society at large. In line with this, Al-Qaradawy (1999) states that Islam is unprecedented in the extent of its care for the poor. Islam establishes the institutions of sadaqah (voluntary charity), zakat (compulsory charity) and Waqf (endowment) to cater for the social needs of the less privileged members of the society. Waqf could be religious which helps in satisfying the religious needs of the society, thereby reducing the direct costs of providing them on the future 
INTERNATIONAL JOURNAL OF ACADEMIC RESEARCH IN BUSINESS AND SOCIAL SCIENCES

Vol. 8, No. 6, June 2018, E-ISSN: 2222-6990 @ 2018 HRMARS

generations. It could also be philanthropic which supports the poor and focuses on provision of public utilities, libraries, medical services, education and scientific research, animal care, environmental protection, credit facilities to the poor, parks, roads, bridge, water supply and other activities which are of interest to the society at large. Finally, Waqf could also be posterity or family which gives the donor the right of first dedicating the fruits to his family members and the remnant if any, to the poor. The family Waqf therefore reduces the social burden of the philanthropist and the government. According to Maidugu (2011), the institution of Waqf results into the flourishing of the cultural, educational and scientific activities as well as poverty alleviation. However, despite all these provisions in Islamic jurisprudence to promote infrastructural development, social development, alleviate poverty and cater for the basic needs of the Ummah, there are a number of challenges faced in Kaduna State. This is because; the state of education in terms of infrastructural facilities in Kaduna State is not encouraging. The rate of poverty is also high in the State, while social services are insufficient.

It could be seen from the above that Waqf is a potent tool for bringing about progress in the society. This is because it could go a long way in making provision for social services and aiding towards poverty alleviation. It should however be noted that this important Islamic duty is facing some challenges which is manifested by the prevalence of infrastructural decay and inadequacy as well as poverty in Kaduna State. It is thus, against this background that this study centres on the contribution of Waqf to provision of social services in Kaduna State and challenges faced in the process of achieving the goal.

\section{Problem of the study}

People in Kaduna State are facing a lot of social challenges such as poor state of education which manifests itself through infrastructural decay, low quality of education, poor quality of school management, inadequacy of qualified teachers and shortage of ICT equipment, poor health supply as a result of ineffective public health to cater for the teeming population of the State and poverty which seem to defy solution. Islam caters for the entire needs of the people in the society through its different institutions such as sadaqah, zakat and waqf which could proffer solutions to the problems. The problem of the study is therefore to determine the contributions of Waqf towards the provision of social services in Kaduna State as well as the challenges faced in the process.

\section{Literature Review}

The word Waqf was derived from Arabic word "Waqf. "In the Maliki School, the word hubs (plural Ahbas/ hubus) is commonly used for the concept of Waqf. The word Waqf means to stop, to prevent and to detain. Islamic jurists interpret "Waqf" as detaining assets that are beneficial and physically lasting to be given as charity. According Ibn 'Arafah (1993), Waqf means to donate the benefits accruable from a property during the time of its existence and being the property of the donor even if the ownership is not actual. This definition implies that any property which its proceeds are devoted to charity purpose and its proprietorship is retained by the owner is called Waqf.

Awqaf is beneficial to the Ummah in the sense that it gives perpetual reward to the donor. According to Bababima (2011), one of the benefits of Waqf could be seen in the perpetual reward which it brings even after the death of the donor. This was confirmed by the saying of the prophet (SAW) who on the authority of Abu Hurayrah said "when a man dies the rewards of his action cease except from three things: a continuous charity, a beneficial knowledge and a righteous son that prays for him". Sahih Muslim (1631). 
INTERNATIONAL JOURNAL OF ACADEMIC RESEARCH IN BUSINESS AND SOCIAL SCIENCES Vol. 8, No. 6, June 2018, E-ISSN: 2222-6990 @ 2018 HRMARS

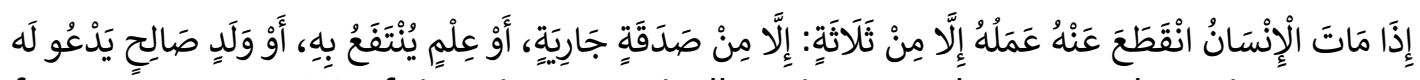
This Hadith therefore encourages Waqf since it categorically points out that reward continues even after the demise of the donor.

To get this reward, Awqaf is being practiced in Muslim societies - both current and the past. This is evident from the information available on the size of these institutions. The prophet (SAW) established Awqaf himself and advised his companions to establish them as such. Many awqaf properties were established for religious as well as charitable reasons. According to Ibn Hisham (1955), the first Awqaf created by the prophet (SAW) was the purchase of a land and the construction of a mosque in Madinah, known up to today as the prophet's mosque. He also mentioned that the seven orchards left to the prophet (SAW) by Mukhayriq upon his death in the battle of Uhud were assigned by The Prophet as Waqf. al-Kettani (1346A.H) added that, the prophet (SAW) used to spend their fruits on his household and for buying weapon for defense.

Also, Ahmed (2004), states that, by the middle of the $2^{\text {nd }}$ century of the Islamic era, Awqaf had already been extended to the medical services. During the Abbasid period, many hospitals were founded and financed by the Awqaf. It was reported that al-Ma'mun built several specialist hospitals for ophthalmology, leprosy, mental health and for handicaps as Awqaf in most of the major cities of his large empire. He also established investment Awqaf to spend on their operational expenses. These Awqaf included agricultural land and businesses and residential rental buildings. In some Muslim countries, Awqaf reached one third or more of total cultivable land and other properties. According to Ahmed (2007) the first land survey in Egypt conducted during Muhammad Ali's rule indicated that 600,000 feddan (acre) were Awqaf out of a total 2.5million feddan (acre) of cultivable land. Most of these Awqaf were for mosques and education and a great chunk was for al-Azhar itself. He further stated that, the large investment in the social sector succeeded in transforming the society and empowering the poor segment of it. Education offered almost only by Awqaf enabled the poor to move up the economic ladder and obtain high levels of economic and political power. Awqaf has always served as the mechanism for the elimination of poverty; supporting families, low socioeconomic groups and professional groups. This is supported by Esmaeli (n.d) that Islamic State and caliphates did not have special departments to support low socio-economic groups or to provide for public works such as roads, bridges, mosques, inns and hospitals. Thus Islamic Awqaf play an important role in supporting social units and help in alleviation of poverty in Muslim societies.

As pointed out by Wakil (2015), waqf was practiced in Northern Nigeria during the time of Uthman Bn Fodio and the major types of Waqf practiced then were the building of mosques which was so rampant then and now that almost every household has a dedicated portion for mosque. In the same vein, lands were donated for cemetery purpose due to the need for such in the Muslim communities. Providing of Islamic education in the houses of scholars is another form that is being practiced (karatun zaure). Guest rooms were also provided for accommodating visiting scholars, strangers and businessmen. There are given opportunities to stay for up to a period of one month. This form is still practiced today in Sokoto at Uthman Dan Fodio tomb where visitors are allowed to stay for a period of three days and complete one month during Ramadan.

Kahf (2003) also highlighted three points as the benefits of Awqaf to the Muslim societies.

i. $\quad$ That the revenue of Awqaf are frequently spent on mosques. This usually includes salaries of Imams, teachers and preachers in addition to carpeting, cleaning, water supply and oil for the lights. With the help of Awqaf revenue, religious leaders and teachers have always been able to take socio and political position independent of the ruling class. He stated an instance of the French occupation of Algeria in 1831. The colonial authority took control of 
INTERNATIONAL JOURNAL OF ACADEMIC RESEARCH IN BUSINESS AND SOCIAL SCIENCES

Vol. 8, No. 6, June 2018, E-ISSN: 2222-6990 @ 2018 HRMARS

the Awqaf properties in order to suppress religious leaders who fought against the occupation.

ii. Awqaf revenue serves as financier for education, which usually covers libraries, books, salaries of teachers and other staff and stipends for students. Financing was not restricted to the religious studies especially at the stage of the rise of Islam. In addition to freedom of education, this approach of financing helped in creating a learned class not derived from the rich and ruling classes. At times, majority of Muslim scholars used to come from poor and slave segments of the society and very often they strongly stood in defence of the public masses and opposed the policies of the rulers.

iii. Awqaf revenue also helps in health services which cover construction of hospitals and spending on physicians, apprentices and patients. A good example of this is Shishi children hospital in Istanbul which was founded in1898.

These imply that Waqf could be important tool for societal emancipation and stimulant to the principle of sharing among the people in the community.

As for the constraints militating against effectiveness of Waqf in Northern Nigeria, Oseni (n.d) identifies the following four factors:

1. The fiqh issues (Issues on jurisprudence): The Maliki School vested the ownership of Waqf to the Waqif (donor) which shows that there is no absolute Waqf and as such the properties given out as Waqf may be revoked at any time since the general belief is that Waqf is revocable. This ability to revoke Waqf is seriously bringing setback for the development of Waqf. There was an instance at Malumfashi road, Tudun-Nupawa, Kaduna whereby a person has given out a particular mosque/land as Waqf and his heir took over the property as an inherited estate.

2. Legal impediment in the resolution of Waqf issues: Before the colonization of Nigeria, Waqf institution was under the office of the emir in Northern Nigeria. But after the colonization, the Waqf law was replaced with modern law of trusts which creates legal impediments in resolving dispute related to Waqf. Waqf matters are subjected to the jurisdiction of the Shari'ah Court of Appeal, but land matters are not within the jurisdiction of the court. A good example of this was the case between Jimri Ganya and Dudu Maza reported in (2015) 8 NWLR part 1460 page 82 @ 93-94.

3. Lack of a dedicated legislation on Waqf: The Northern States of Nigeria that introduced Shari'ah by introducing the criminal aspects of Islamic law (hudud) with no clear legislation on Waqf.

4. Lackadaisical attitude of the Muslim leaders: Oseni (n.d) explained that despite the current state of affairs in Northern Nigeria, the Muslim leaders particularly those who have acquired political power have failed to initiate reforms in the system. Some feel Waqf is not so important in the administration of the State.

It can also be deduced from Karim(n.d) that the following factors also militate against effectiveness of Waqf in Northern Nigeria:

i. Low participation: The long perception of people about Waqf has been that Waqf are created only with real asset and usually mosque. As a result those who are not in possession of real assets failed to participate in Waqf. To justify the issue of low participation, Alhaji Yunusa Ya'u, the then Secretarial Secretary of The Kaduna State Standing Committee on Zakat and Awqaf and now the 
Director Planning, Research and Statistics of the Kaduna State Bureau for Islamic Affairs in an oral interview conducted in 2017 stated that throughout the thirteen years (2003-2016) of its existence, The Kaduna State Standing Committee on Zakat and Awqaf, received only $=\mathrm{N}=290,500$ as dedicated fund for Awqaf.

ii. Improper utilization: charitable endowments are made under different headings in Islam. The biggest two of these sectors are Zakat and Waqf. Zakat which is an obligation of all wealthy Muslims is being paid by most of them, but its expected effectiveness has been hampered by some factors which include inefficient collection, distribution and distribution in unproductive usage. Similar experience if not worse, has been the case regarding Waqf in most Northern states of Nigeria.

The aforementioned are therefore, some of the factors making it difficult for Muslim communities to get the much desired benefits of Awqaf. These challenges need to be properly addressed in order to tackle the social and economic challenges which the institution of Awqaf is out to proffer solution to.

\section{Methodology}

The study adopts the survey research design. The population of the study was made up of the entire donors, administrators and beneficiaries of Awqaf properties in Kaduna State out of which three hundred were purposively selected. The interview technique was used to collect the data from the respondents which were reported by the researcher.

\section{Research Objectives}

The objectives of the study were to:

i. determine the contributions of Awqaf to the provision of social services in Kaduna State.

ii. find out the challenges militating against the effectiveness of Waqf in Kaduna State.

\section{Research Question}

The following research question was developed to guide the study.

i. What are the contributions of Awqaf toward the provision of social services in Kaduna State?

ii. What are the challenges constraining the effectiveness of Waqf in Kaduna State?

iii.

\section{Data Analysis}

The data collected for the study are presented as follow:

Research Question one: What are the contributions of Awqaf toward the provision of social services in Kaduna State?

The interview conducted on the donors, administrators and beneficiaries reveals that Awqaf are significantly contributing toward the provision of social services in Kaduna State. This is because it has been used for establishment of Schools among which are Al-Huda Centre for Islamic and Western Education, Gwargwaje, Zaria, Annuwarul Islam, Kwarbai, Zaria, Ma'ahad Ubayyu binu Ka'ab, Anguwan Mazan gudu, Zaria, Ma'ahad Hayatudinil Islam, Anguwan Kaura, Zaria, Ma'ahad Nurul Islam, Rimin-Doko, Zaria, Ahbabul Mustapha Islamiya, Ikara, Madrasatul Tarbiyatul Islam, sabuwar Tasha, Ikara, Saqafatul Islamiyah, Paki, Abdulaziz Islamic School, Tudun-Wada, Kaduna, Madrasatul Tarbiyatul Islamiya, Unguwar Sanusi, Kaduna, Musbahul Islam School, Unguwar Rimi, Kaduna, School 
INTERNATIONAL JOURNAL OF ACADEMIC RESEARCH IN BUSINESS AND SOCIAL SCIENCES Vol. 8, No. 6, June 2018, E-ISSN: 2222-6990 @ 2018 HRMARS

for Married Women, Kawo, Kaduna, and Sardauna Memorial college, Kaduna. These constitute the largest volume of social services provided by the institution of Awqaf. The interview also reveals that Awqaf are used in the provision of medical facilities in Kaduna State. The medical centres established through cash Wqaf include; FOMWAN Hospital, Badarawa, Kaduna, Attatbiq Hospital, Kinkinau, Kaduna, Muslims' Specialists Hospital, Dan Magaji, Zaria, Amaru Health Clinic, Amaru, Zaria and Dental Clinic, Ikara. As for skills acquisition centres, the interview shows that those that were established with the aid of Awqaf include; IIRO Skills Acquisition Centre, Faskari road, Kaduna, Usman Danfodio Skills Acquisition Centre, Unguwar Sanusi, Kaduna, Initiatives for Muslim Women in Nigeria (IMWON) skills Acquisition Centre, Anguwan Kaji, Kaduna Almannar Women Association Training centre, Rigasa, Kaduna, Almannar Women Association Training centre, Rafin Guza and Kaduna and al Ihsan Foundation, Fertilizer Road, Kaduna.

The interview also reveals that Danbo Cemetery along Jos road, Zaria, Kwarbai Cemetery, Zaria, Ma'ajin Amaru Cemetery, Zaria, Lungu Cemetery, Ikara, Unguwar Bishar Cemetery, Zaria, Bashama Road Cemetery, Tudun-Wada, Kaduna and Makarfi Road Cemetery, Rigasa, Kaduna were established through Awqaf. Some orphanage homes were also set up with the aid of Awqaf. These include; Aytam (Orphans) Foundation College, Saminaka Street, Gwargwaje, Zaria., Nurul Huda Anguwan Kaji, Kaduna and MWON Islamiyah School, Dutsen-Mai Daji,Igabi Local Government, Kaduna. Finally, the interview also points out that libraries are not left out and they include the Islamic Learning Centre Library, Katuru road, Kaduna, Sheikh Muntaka Commassie Library, Zaria and Sheikh Ladan Shareu Library, Zaria

It should be noted that the interview revealed contribution towards the provision of medical facilities, skills acquisition centres, libraries and cemeteries are minimal.

Research Question Two: What are the challenges constraining the effectiveness of Waqf in Kaduna State?

The interview conducted on respondents reveals that the greatest challenges constraining the effectiveness of Waqf in Kaduna States are:

1. Low participation by people which made the Kaduna State Zakat and Awqaf committee to generate little fund that were not even enough to take care of the committee's administrative requirements.

2. The dissolution of the Kaduna State Zakat and Awqaf committee by the government of Mallam Nasir Ahmad el-Rufa'i leading to the transferring of the responsibility to the traditional institutions.

\section{Discussion}

This study was conducted in order to determine the contributions of Awqaf to the provision of social services in Kaduna State as well as the challenges the institution is facing in the State. The findings revealed that Awqaf contribute toward the provision of social services such as schools, heath cenres, skills acquisition centres, orphanage homes, libraries and cemeteries. These findings are in line with the view of Kahf (2003) which point out that Awqaf revenue serves as financier for education, which usually covers libraries, books and health services which cover construction of hospitals and payment of physicians. The findings also support the position of Tohirin (2010) who said that the activities of Awqaf might lead to provision of public services such as educational services, orphanage shelters, and medical facilities. The findings also show that low patronage and attitude of political office holders are the greatest challenges confronting the institution in Kaduna State. These corroborate the view of Karim (n.d) which highlights low patronage as an impediment to Waqf and Oseni (n.d) 
INTERNATIONAL JOURNAL OF ACADEMIC RESEARCH IN BUSINESS AND SOCIAL SCIENCES

Vol. 8, No. 6, June 2018, E-ISSN: 2222-6990 @ 2018 HRMARS

who points out that the feeling by some political office holders that Waqf is not so important in the administration of the State.

\section{Conclusion}

This study was carried out to find out the contributions of Awqaf to provision of social services in Kaduna State. The study revealed that Awqaf are contributing toward the provision of schools, skills acquisition centres, medical centres, orphanage homes, cemeteries and libraries. It also revealed the poor participation by people and the dissolution of the Kaduna State Zakat and Awqaf committee by the government of Mallam Nasir Ahmad el-Rufa'i are the greatest challenges affecting the effectiveness of Awqaf in Kaduna State. The implication of these is that waqf is a social insurance scheme contributing towards the provision of social services which all wealth to do Muslims in the society are expected to contribute to in order to cater for the needy, underprivileged ones and the society at large.

\section{Recommendations}

The following recommendations are suggested as the way forward based on the findings of the study and the conclusion that was drawn:

1. There should be increase in volume of skills acquisition centres, medical centres and libraries set up through the institution of Awqaf. This is because, the study revealed that schools constitute majority of the social services provided through the institution of Awqaf.

2. Kaduna State Government should reintroduce the Zakat and Waqf Board instead of transferring the responsibility of collection and distribution to the Traditional Rulers.

3. There should be increase in participation by wealthy Muslims in Kaduna State through devoting some of their properties for the purpose of waqf.

\section{Reference}

Ahmed, H. (2004). Role of Zakat and Awqaf in Poverty Alleviation. Islamic Research and Training institute, occasional paper No 8.

Ahmed, H. (2007) Waqf-Based Microfinance: Realizing the Social Role of Islamic Finance. A paper presented at the Singapore International Waqf conference.Ibn Arafah,(1995), Sharh Kitab al Hudud, Lebanon: Dar al Arab Wal-Islamy.

Al-Kettani, A. (1346 AH).Al Taratib al Idariyya. Rebat: al Matba'ah al Ahliyya.

Al-Qaradawy, Y. (1999). Fiqh az-Zakat (A Comparative Study of the Rules, Regulations and Philosophy of Zakat in the Light of the Qur'an and Sunnah). London: Dar Al Taqwa Ltd.

Bababima, M. (2011). The Institution of Waqf According to the Maliki School of Thought and its Application in Northern Nigeria. A masters seminar paper presented to the

Department of Islamic Studies, Usumanu Danfodio University, Sokoto.

Esmaeli, H. (n.d). The Relationship between the Waqf Institutions in Islamic Law, and the rule of Law in the Middle East. Retrieved from www.wagfacademy.org on October 5, 2012. 
INTERNATIONAL JOURNAL OF ACADEMIC RESEARCH IN BUSINESS AND SOCIAL SCIENCES Vol. 8, No. 6, June 2018, E-ISSN: 2222-6990 C 2018 HRMARS

Ibn Hasham (1955). Al Sirah al Nabawiyyah. Cairo: Babi al Halabi publishers.

Kahf, M. (2003). The Role of Waqf in Improving the Ummah Welfare. Paper presented to the International seminar on waqf as a private legal body. Organized by the Islamic university of North Sumatra, Medan, Indonesia.

Karim, R. (n.d). Zakat and Waqf Bank for Social Development and Improved Management of Endowments. Retrieved form www.ihmsaw. Org on 8 October, 2012.

Maidugu, A. A. (2011). Alleviating of Poverty in Nigeria: An Appraisal of the Role of the Zamfara Zakat and Endowment Board. In Salihi, A., Umar, F.A. and Suleiman, H.A. (ed). Shari'ah Democracy and Governance in Islam. Lagos: Departments of Political Science and Islamic Studies and International Institute of Islamic Thought (IIIT) (Nigeria's office).

Oseni, U.A. (n.d) Towards the Effective Legal Regulation of Waqf in Nigeria: Problems and Prospect. Retrieved form http://ssrn.com on October 5, 2012.

Tohirin, A. (2010). The Cash Waqf for Empowering the Small Businesses. Paper presented at the seventh international conference- the Tawhid Epistemology: Zakat and Waqf Economy, Bangi, 2010. 